\title{
CESIS
}

Electronic Working Paper Series

Paper No. 139

\section{What does it Mean Conceptually that Universities Compete?}

\author{
Enrico Deiaco ${ }^{1}$, Magnus Homén ${ }^{2}$ and Maureen McKelvey ${ }^{3}$ \\ ( ${ }^{1}$ SISTER and CESIS, ${ }^{2,3}$ Chalmers Institute of Technology)
}

September 2008

The Royal Institute of technology

Centre of Excellence for Science and Innovation Studies (CESIS)

http://www.cesis.se 


\section{What does it mean conceptually that universities compete?}

Enrico Deiaco ${ }^{1}$, Magnus Holmén $^{2}$ and Maureen McKelvey ${ }^{2}$

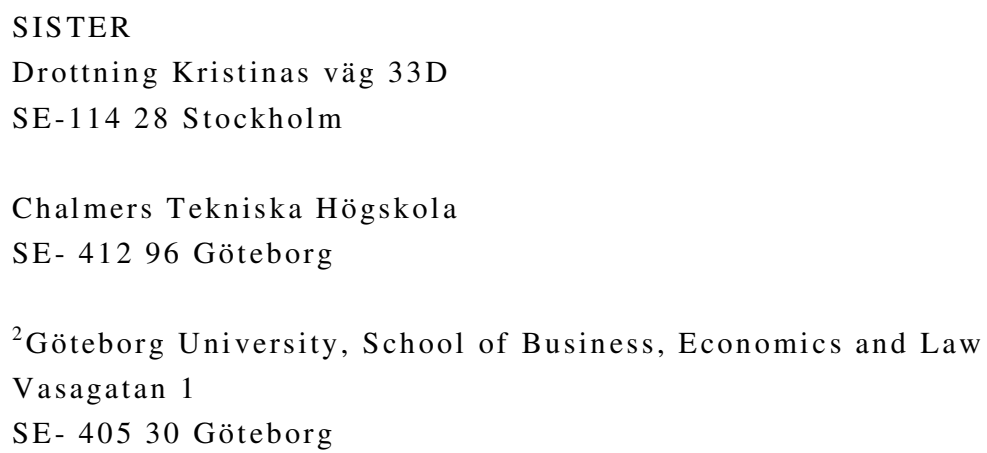




\section{Introduction}

This article addresses the issue of how and why European universities are learning to compete, in a situation where the national institutional context and sectoral conditions are undergoing transformation. This view is quite a long way from traditional views of academics. Academics are to some extent localized to the specific university that pays their wages, and yet they also share a world of beliefs, value and experiences with academics located around the world. Robert Merton (1973) articulated a world in which scientists evaluated knowledge based on an ethos of universalism, organized scepticism, disinterestedness, and communism. ${ }^{\text {i }}$ The Humboltian ideal of the university from Germany was also very influential for the 'research universities' and similarly defines a particularly type of mission to society and way of organizing. This view projected a university based on three formative principles: unity of research and teaching, freedom of teaching, and academic self-governance (Shils 1997). However, the contemporary environment of researchers, teachers and students seems to be moving far from these ideals. One can see that these new competitive regimes for national universities within Europe are related to factors such as: a) Increasing globalisation of students, resources and faculty; b) Changes in national public policy for education, science and innovation; and c) Changes in business R\&D strategies. Underlying these changes are the increased recognition and importance of the role of knowledge in creating economic wealth of nations and individuals as well as firm profits. This means that universities in some respects are becoming more central and more integrated to nations and firms' economic activities than previously. The reason is that their mission to create, renew and transfer knowledge has become a prized asset and commodity in the modern economy. Therefore, as universities are becoming more of a core organization to society in this sense, then more focus should be put upon critically observing their activities and the broader transformations on-going.

Because of these broader changes, European universities - from top leaders, faculties, research groups and individual employees - are increasingly forced to explain to many stakeholders about how, whether, and why their scientific knowledge and educational programmes are relevant to society or not. For example, if universities are not contributing to public and private goods, why should society continue providing resources? Why should students pay for 
education, if the individual returns are too low? Why should companies and private foundations pay for research, if the results are not directly relevant to their goals? How can the efficiency and productivity of the university be improved - and which metrics can be used to demonstrate that those goals have been met? What are the dilemmas and trade-offs that this new competitive regime imposes on the functioning of universities and of society? These are the types of questions currently raised within universities in Continental Europe and Nordic countries, and ones that university leaders, faculty and staff will have to answer. Or else, they should raise new types of questions and perspectives about the role of the university in society.

Despite - or perhaps because of - their new roles, these organizations face significant economic and political challenges, which arise due to on-going massification and internationalization of research and education as well as demands on higher quality, 'measurable' outcomes, and explicit economic benefits. Universities in Continental and Nordic countries are thus now moving to a new competitive regime, where universities are becoming 'knowledge businesses' in trying to become more similar to firms in how they conceptualize their 'business', develop strategy, act to renew their service offerings and exploit their existing resources (staff and infrastructure) and capabilities. However, this means that universities struggle to find their particular solution to balancing their traditional roles of research, teaching with immediate demands of societal usefulness. Traditionally, many universities focused on the long-term. Usefulness in the past could be defined in terms of developing new areas of knowledge through research for use in future decades - and of widening the societal base of new knowledge through teaching and diffusion of students. However, universities now face clear demands of producing immediately usefulness knowledge to students, businesses and society (enhanced amongst other by the Bologna process). The pressures on the university to quickly respond to societal and industrial demands have thus been more forcefully articulated in recent years. If these organizations wish to retain the traditional values of scholarship, they will need to do so, in parallel with understanding - and changing - their selection environment in the future. Hence, here, we focus upon the competition aspect from a Schumpeterian view, in order to draw out the logical conclusions but we do not focus upon whether those outcomes are desirable or negative. We choose this focus because we know that universities play major roles in the knowledge society, and current debates within the EU indicate that we will see additional 
major changes in the national institutional context and global markets. Yet this article only makes some initial steps towards understanding how European universities are changing, as well as whether and how well European universities and colleges are learning to compete, in comparison with their global competitors and collaborators. For future analysis, we will need more precision in whether competition exists in the university system, especially what competition means, and how metrics and feedback loops affect the distribution of winners from losers, the latter which is called selection mechanisms in the evolutionary literature. This article therefore turns to more abstract questions, such as whether competition exists amongst universities and if so, what are the major trends and future outcomes of this shift from a social institution to a knowledge business. Thus, do universities really compete? And if so, how do they compete? And over what?

\section{Does competition exist in the university sector?}

Park (1998, p. 347) points out that competition is a pivotal concept in economics, so different interpretations of the concept are worth detailing here. Students 'learn of perfect competition as a particular market structure that consists of a large number of perfectly knowledgeable buyers and sellers who are individually too small to affect the market price and who engage in the exchange of a homogeneous good'. It is also often assumed that increased competition pushes GDP upwards but do not affect the shape of the long-run GDP-development although the new growth theory certainly challenges this view (Romer 1986) showing amongst other things, the existence of increasing returns to scale.

This simple view on perfect competition is sometimes associated with negative connotations such as struggle, rivalry and extinction of socially productive actors, values and behaviour. This simple text-book mode of describing perfect competition has been developed and made more realistic by incorporating a much more sophisticated description on how various actors economize on information (Stiglitz 1993). Thus, the textbook model of perfect competition requires the absence of strategic interaction - e.g. firms do not take into account the possible responses of other firms to their own actions' which is a poor description of the competitive process. 
This article sees competition from a modern Schumpeterian perspective in theories of innovation and entrepreneurship, where successfully competing means that an actor is able to innovate, interact with the environment, and respond to changes. Many evolutionary inspired social scientists have taken a broader view on the role of competition viewing it as mainly a process of discovery and experimentation (Schumpeter 1942, Dahmén 1950, Eliasson 1990). In order to satisfy customers a producer is forced to constantly modify or create new products or services mainly by innovating. It has to produce the same products to a lower price or introduce new products that have a better price and performance ratio. This process is viewed as a discovery and experimental process where new knowledge is invented or where new knowledge is combined with older knowledge to introduce new products and services. Only a test on the market will show which experiment will be successful. In practice, this view of the competitive process mean that competition will coexist with co-operation, that new entry of firms will co-exist with exit and that expansion is as common as closures. In the broader perspective, this joint interactive process will result in dynamics that generate positive and long term growth GDP-growth.

When we started working, questions arose about whether universities compete or not, whether there were positive or negative implications, and so forth. Many colleagues from Continental Europe and Nordic countries argued that European universities do not compete, at least not in the sense companies do nor in a way that the economic and static model of perfect competition suggest (see e.g. Engwall 2007). For many, universities represent social institutions and bastions of learning for future generations where the universities, colleges and the like are deeply entrenched societal institutions, as a place for critical, independent debate. So, the response was that any competition that arose would not be of the economic type, but it would instead be around values, prestige and reputation. Various arguments and assumptions were brought forth, about the special nature of universities and the obvious lack of competition. In contrast, colleagues from North American, Australian and British institutional contexts clearly knew that competition existed - mainly because they had lived within a science and R\&D system, driven by specific metrics and management techniques. They were only too aware that competition did exist, and many of them were wary of the long term and unintended consequences. ${ }^{\text {ii }}$ 
These divergent opinions had a positive effect, in that it stimulated us to start to think more deeply about theoretical and empirical implications of a Schumpeterian, innovation and evolutionary perspective. When we then started looking more closely at the empirical material about European universities, we felt that many of these arguments against the whole notion that universities compete became weaker. This strengthened our conviction that universities will increasingly have to act like innovative firms - even though we know little about how these changes may have long-term effects. More should be done, to discuss whether the long-term effects are positive or disastrous and whether they may preserve core values or change them completely. Let us address some of these arguments against the whole notion of competition in this sector directly:

First, European universities are not competing because they are regulated. It is correct that the higher educational sector is very regulated and dependent upon government financing. But the same is true for the pharmaceutical industry, but no one would argue that pharmaceuticals do not constitute an industry, competing on a global scale. Moreover, the pharmaceutical industry is certainly characterised by the sales of high products of the high upfront but low marginal costs, but this is not that different from much university teaching and research which are services of a high upfront cost but low marginal cost kind. This implies that a change in the regulation of universities could lead to a similar change of the university sector as the pharmaceutical sector underwent, such as mergers, large actors coordinating complementary assets and new actors focused upon discovery and development, . Indeed, higher education is being deregulated around the world. Deregulation in the higher education sector takes many forms. Examples include the current debate for more autonomy of universities, the emphasis on research excellence as a mechanism for distribution public funding, and current GATS negotiations on liberalizing services, including education services. A better analogy to the ongoing transformation may therefore be the deregulation of telecommunications and PTT in Europe. These were national champions and great bastions of technology, communicative resources and the like. Yet they have been deregulated and now fight on the global - and on very limited local - markets. Hence, an important issue is what strategies, niches and outcomes are possible as research and higher education become deregulated. 
Second, government funding is allocated in a non-competitive manner. Our view is that this was true in the past, but rapidly changing. Clearly, in the past, many European national governments allocated financing to HEIs in a non-competitive manner, but this is changing (Frölich 2008). Traditionally, governments provided fixed funding and budgets, based on allocations from previous years. However, public policy in Europe is increasingly moving towards internal competitive mechanisms to allocate financial resources to education and research. Public funding is given, based on metrics for outcome goals such as publications to measure research excellence, number of active professors per student to measure the science in teaching, and number of $\mathrm{PhD}$ degrees granted to measure higher-level training. These types of funding schemes introduce more competitive and outcome related selection environment, in the sense that organizations change their organizational and incentive structure to realize those performance measures. The most elaborate system is the U.K. research assessment exercise (RAE), which has been conducted five times since 1986. Although the data measuring the effects of RAE on performance is rather evidentiary and flimsy, several studies suggest that the exercise has strengthened research performance of universities in the U.K. and Australia (Butler 2003; Hicks 2007). Many discussions are now underway as to whether, and what system should come after the 2008 RAE in the UK, as well as how to implement similar mechanisms in other countries.

Our interpretation of these trends suggests that European government funding is increasingly based on a type of competition, and universities will have differential positions, where rankings and performance measures will affect resource allocation. Rationales for changing these mechanisms may differ, such as to raise quality and to diffuse education to groups normally not taking advanced degrees. This implies that the government no longer just hands out financial resources, where future budgets will simply reflect previous years. Instead, the universities increasingly have to demonstrate results, as an outcome of the financial resources which society invests. So, de facto, HEIs will have to perform and to compete increasingly in national institutional contexts, based on specific criteria for selection to allocate resources.

Third, there are not any markets, and therefore there cannot be competition. This assumption is to some extent based on a traditional neoclassical view of competition, where a particular type 
of market can be assumed to exist and play a central role as a coordinating mechanism. We agree that this type of market mechanisms does not dominate higher education and research in most of the countries we studied.

However, more modern economic theory and other theoretical perspectives have studied a number of diverse forms of markets and also how market 'mechanisms' may be at work, even without a 'pure market'. The questions then become quite different, such as what is the equivalent of the market, and what is being traded, at what price?

Education clearly is - or is becoming - a knowledge-based service, for sale at a price. That price is often differentiated based on home country (or other geographical aspect) of the student as well as by characteristics of the provider. In the USA, for example, one can clearly see that different 'quality' and mission of educational services command different prices. Countries differ in how far education has become a knowledge-based service as opposed to a public good. This is not surprising as research shows that the transformation from a national, social institution to a market actor takes time regardless of sector. Still, the UK in recent decades shows how quickly a national institutional context can move from the idea of free education in the 1970s to a pay-as-you-go system today. In other countries like in Sweden, the idea of taking fees from students still meets strong resistance, but discussions are underway to introduce fees - but only for international students outside the European Union. Moreover, many countries like Italy and Spain now allow parallel private and public systems. In comparison with education, it is perhaps less clear whether, and how, research is a knowledge-based service for sale, to the same extent as education. In some cases, university-industry interaction does provide direct funding for research, where firms purchase a type of service, albeit usually one difficult to define. A 'market' may be developed in other dimensions, such that the UK labour market pays quite a premium for highly cited academics publishing in top journals - even for part-time or post-retirement affiliation. ${ }^{\text {iii }}$

Fourth, the majority of funding is from government agencies, not firms. This statement is similar to the above two, but focuses more upon the source of funding. In fact, the validity of this statement varies greatly, depending both on the discipline analyzed and the national context (Bonaccorsi \& Daraio 2007). Some aggregate trends also indicate changes. OECD statistics 
indicate that between 1981 and 2003, the percentage of government-funded academic research has decreased by 10 percent, and the share of the business sector in the financing of higher education R\&D has doubled and reached 6\% in 2003 (Vincent-Lancrin 2006). This business financing is unevenly spread across fields but also across universities. Case study type of evidence from specific HEIs indicates that many are working to position themselves, to compete from additional industrial funding. Budget autonomy is part of the push towards deregulation, as well. These changes will have implications for the future. If money and budget autonomy is correlated with good research performance as new research seems to indicate (Aghion et al. 2007), then we would expect the universities and HEIs to have even more diverse income streams in the future.

Slaughter and Leslie (1997) identify and analyze an important phenomenon in these changes. They discuss 'academic capitalism' which they define as the market or market like efforts to secure external monies. External monies from new sources such as alumni are of great significance within some national institutional contexts. For example in 2007 the leading ten universities in the USA all managed to raise funds over 300 million \$ while Harvard alone in 2006 had an endowment of well over 25 billion \$ (CAE 2007). Of course, the ability to raise funds and to rely upon income from endowments is highly skewed among universities. Therefore, this is one major reason for the differences in what an individual university does and what it can accomplish.

However, the increasing reliance on external funding is only part of the story of how universities in many countries are changing their behaviour. Thus in contrast to Slaughter and Leslie (1997), our approach to understanding universities as competing is somewhat broader as we intend to capture changes across the three roles of the university; research, education and third mission.

Fifth, universities do not act like firms. University leaders talk about strategy and competition but don't know what they are talking about. These statements are impossible to validate or reject, and similar statements could be made about strategy in firms. Still, there are reasons to discuss similarities and differences. Engwall (2007) argues that even if universities today are 
increasingly adopting management methods and rhetoric, they still cannot be labelled corporations since they remain professional organisations with unclear ownership structure and aiming for reputation and prestige rather than profit. However, the boundaries do certainly change, and effects are similar to competition amongst firms. Empirical studies show that universities have emergent strategies (rather than deliberate), which can be defined and measured as positioning in the multidimensional output space (Bonaccorsi \& Daraio 2007). The very same studies show that universities try to differentiate themselves by taking specific strategic positions such as specializing in certain fields. Moreover, this differentiation does lead to observed and large benefits for those that act strategic. This process of differentiation is however limited in Europe by various institutional constraints at the national level. An example of one such constraint would be the lack of autonomy of many European universities because they are government agency. Perhaps the greatest difference between firms and universities is the highly decentralized power structure of universities and the limited or even negligible power of the vice-chancellors. This stands in quite a contrast to the power of CEOs to for example hire and fire staff. This does not mean university strategy does not exist. Instead, strategic actions take place on different levels within the organization. Still, some changes towards very large research centres and integrated Masters Programs seem to favour that strategic decisions are taken at the top level. Concepts of strategy and competition are often fuzzy, and difficult to capture precisely, and certainly university leaders at many levels are trying to incorporate this type of thinking into their decisions and resource allocation.

\section{What might learning to compete mean in the university sector?}

One of the aims of this book is to further conceptualize what it means that universities are competing. Buzzwords like strategy, quality, global player and competitive edge have become de rigour for university managers and for policy-makers within Europe. This occurs at the same time as the European conception of the 'usefulness' and 'value-added' of the university, college and technical institute is slowly changing. It is changing from a primarily national institution serving the public good to a population of diverse actors trying to attract resources and competencies in order to grow and survive. To understand the changes, we propose using 
evolutionary-inspired theories of the role of knowledge, uncertainty and opportunities for transformation in the sector and for the pressures placed upon the organization. This paradigm stresses transformation as an intrinsic feature of the economy and the importance of knowledge and of positioning the organization to identify, act upon and realize innovative opportunities. To do so, we must understand universities as strategic actors, especially as we can empirically observe that the top organizational leaders and also research groups are developing competencies and responding to pressures for change (e.g. Slaughter and Leslie 1997, Slaughter and Rhoades 2004, Shattock 2003). This section therefore answers a series of questions, of what learning to compete might mean in the university sector.

1. Does existing literature already cover the issues of competition, learning and strategic actors?

Universities have been the subject of much research (e.g. Birnbaum 1990, Bauer 1999, Fuller 2000) within many different traditions such as Economic Geography, Innovation Studies, Science and Innovation Policy, Triple Helix, Innovation Systems, Technology Transfer, and Economics of Science each address different issues. Key existing university literature has addressed their role in constructing regional advantage and clusters and more broadly how universities act as vital institutions within the innovation system (Cooke \& Piccaluga 2004; Asheim et al 2006; Braunerhjelm \& Feldman 2006; Etzkowitz \& Leydesdorff 1997). Economics of science focuses on the justification of public basic research, the connection between science and technology, the individual scientist's incentives for conducting research and research productivity, funding regimes and scientific labour markets (see. e.g. Dasgupta \& David, 1994; David, 1994; McKelvey 1996; Stephan, 1996, Salter and Martin 2001). A vast amount of literature has been written specifically on university-industry interactions. Topics include relationships between science and technology on university patenting; on academic entrepreneurship and start-up companies; and on the functioning of technology transfer offices and university support structures (Mansfield \& Lee 1996; Salter and Martin 2001; Mowery et al 2001; Shane 2004; also Nowotny et al 2001, Ziman 2000). A number of pieces examine the 'entrepreneurial university', with an emphasis on technology transfer and related issues (Etzkowitz 2003). Each tradition has its own set of ideas and results. 
With a few exceptions, the existing literature generally does not address universities as strategic and competing actors in the way done in this book. Still, if one wishes to re-interpret those existing results within our conceptual framework, then that literature does provide many detailed empirical insights about single cases as well as background information about specific national institutional contexts. Given the overall lack of attention to the topic, this implies that such a re-analysis as well as more empirical work and theoretical explanations are needed specifically about the changes in how universities and research groups compete for scarce resources, react to institutional changes, and develop competencies.

\section{What do we mean by the transformation from social institution to knowledge business?}

In an earlier book, Flexibility and Stability in the Innovating Economy, McKelvey and Holmén (2006) stressed that transformation of the economy involves an inherently dynamic and complex system, consisting of diverse components and elements, which are interacting and changing in different ways over time. Economic transformation therefore refers to a nonreversible process, referring to quantitative and qualitative changes in components and connections, and often driven by opportunities, defined in a broad sense. These processes may be driven by processes of complexity and self-organization, as well as processes of adaptation and co-evolution.

Hence, the starting point for this article is that the European universities are trying to survive and change - due to internal factors and pressures as well as external ones in on-going processes of transformation. To understand that, we need to analyze emergent strategies and competition, the impact of national context and global trends, as well as rethink 'accepted wisdom' about the roles and mechanisms available for universities to compete. Actors must position themselves, and chose to learn, react or exit niches.

By this idea of 'transformation from a social institution to a knowledge business', we wish to capture the notion that universities are increasingly competing against each other, as places where knowledge is reproduced, transferred, developed and applied to specific problems. The universities are in the knowledge business. Therefore, universities must compete for financial and intellectual resources to cover costs for students and staff, and in an increasingly performance-driven European context. They must also compete in the provision of intangible 
service outputs like quality of education, research impact, and societal relevance. This implies that we need further conceptual understanding of scarce resources, uncertainty, and the necessity of using competencies and resources in order to deliver knowledge-based services through core organizational activities. How they do so is another matter, since acting like a firm may not be the answer. Indeed, it is plausible that later research might find that the traditional values, missions and organizational forms of the research universities enabled them to 'compete' in the way defined here, under specific historical institutions. Still, what we need to better understand is what the modern competition and competitive regimes may mean for the future of European universities.

\section{What do we mean by competition, in general?}

If we look more closely, there are at least three different conceptualizations of competition. These can be found, respectively, in the neoclassical economics literature, the Schumpeterian and evolutionary economics literature, and the modern value creation and knowledge based literature (Park 1998; Saviotti and Krafft 2004, Slywotsky 1996). The first conceptualization views competition from a resource allocation and efficiency perspective (Park 1998). The economic system is coordinated by the market mechanism. Much analysis within this paradigm views competition either on price competition between producers or consumers on a market or the competition among firms producing the same economic good (Park 1998; Saviotti and Krafft 2004). This view assumes that if one wants to understand competition within the economy, then one should either focus on market mechanisms and/or upon a population of firms that are within the same sector because they are selling substitutable products.

The second conceptualization of competition comes from Schumpeterian views of the economy as a dynamic process of rivalry amongst firms in which only the fittest survive and thrive (Nelson 1959; Metcalfe 1998). In this view what separates the successful from the unsuccessful competitors is the ability to create, invent and innovate (Park 1998). The third view is similar to the second but comes from management literature. Here, there is even more focus on the strategies, business models and resources and capabilities of individual actors. Relevant underlying paradigms can be found within business economics and related fields such as strategic management, which also have other dimensions of differences between definitions of competing and competition (Penrose 1959; Slywotski 1996). 
Our view combines the second and third perspectives on competition. ${ }^{\text {iv }}$ One starting aspect is the overall system. From an economists' viewpoint, Saviotti and Krafft (2004) develop a definition of competition, which they claim combines the first and second theoretical perspectives. In their view, competition is based on three aspects: competition as interaction (amongst firms), competition as involving qualitative change, and competition as an on-going process. Krafft (2000) and Saviotti and Krafft (2004) define competition to involve rival firms, industries, markets, as well as the techniques of production. 'Competition is a process of rivalry between firms which takes the form of contests within existing markets (intra-industry competition), and the form of potential entry into new areas (inter-industry competition). Competition includes rivalry in terms of price, but also in terms of altered or improved techniques of production or products, and in terms of the provision of information to consumers about products' (Saviotti and Krafft 2004, p. 2). Thus, one central aspect of competition is that when two actors compete, their relative success depends on the views of some other, third party. Normally this party is a paying customer or by some social representative, such as the state. In our interpretation, they have added a dynamic element to a traditional definition of competition, but retained the focus upon overall system and exchange of resources within the market system.

This implies that by combining the second and third perspectives, we can propose a new direction for understanding universities learning to compete. In contrast to the first perspective and some evolutionary approaches, universities are seen not as some kind of calculating machine that simply adapts to signals and changes in its environment. Therefore, an important aspect in this article is the opportunities in the environment and the competencies developed by strategic actors, as further discussed below.

4. How to understand competition in universities, by combining a Schumpeterian and competence-based view of the firm?

Universities are here seen to be actors which respond to signals in the environment but also active affect their selection environment, and in doing so, they also have diverse and sometimes unique competencies, resources and strategies. Universities are constituted not only by visible leaders like vice chancellors, presidents and deans but also by research groups and faculties, student bodies, and individual researchers. People within universities work to shape their 
internal processes as well as their environments, and these decisions and actions represent active 'pushes' to change things as well as more passive 'responds' to internal as well as external pressures.

From a dynamic perspective, competition is the process in which actors (individuals, firms or other organisations) act to improve their access to scarce resources that can fulfil their wants or needs. Access can refer to the existence of a resource as well as to the ability of an actor to get hold or create such a resource. Core to competition is that it is not enough to do something but to do it so effectively or efficiently compared to its competitors that it can 'afford' to continue to operate. ${ }^{\mathrm{V}}$ In part explained by external events, competition is dynamic and is never at rest. Just as important are the endogenous processes of consumption, production, institutional changes, and innovations (Potts and Foster 2006). In any actor system, the actions of one affect actions of others (March 1996). Such ongoing processes internal to any economic system create uncertainty in terms of what the scarce resources are, and consequently what actors compete over and how they compete (Lane and Maxfield 2005, Metcalfe 1998). Thus, time, perception and actions must be an explicit element of the conceptualization of competition (e.g. Hayek 1937).

To compete then means that an actor undertakes actions to advance its situation under uncertainty but where these actions themselves create uncertainty. Consumption and production affect scarce resources differentially as these processes transform, destroy or even increase the availability of resources. Innovation and institutional changes affect the scarcity of resources as they hinder or steer consumption and production towards some but not other resources. Innovation affects the range of offerings that are made to customers but also how these offerings are created and distributed.

Therefore, when studying industries and firms, our theoretical perspective of combining Schumpeterian economics and competence-based theory of the firm leads us to stress the role of opportunities in creating new activities and enterprises in relation to changes in investment (Schumpeter 1942; Hanusch and Pyka 2007). A first insight has to do with opportunities for change. Empirically it has been demonstrated that over time different technologies and research are consistently characterized by different levels of opportunities, i.e. the likelihood of coming up with some novelty differ greatly depending on the nature of the technology or the problem 
(e.g. Klevorick et al 1995). Another theoretical insight relates to opportunities related to capabilities. The innovation management literature deals with how individual actors such as entrepreneurs perceive, identify, act or construct opportunities (Shane 2004; Holmén et al 2007). This is greatly affected by the resources and the capabilities available to the organizations as they construct what they can and should do (e.g. Penrose 1959). As organizations 'add' or terminate capabilities over time, they also continuously leverage their accumulated capabilities, meaning that they are both path-dependent and path-breaking. The end result of this process is differentiation among various universities and therefore division of labour.

\section{Who is competing in the university sector?}

The question remains of who is competing in the university sector. Given the top-down style of many recent strategic initiatives in European universities, strategy and competition have been increasingly seen as something for the 'university as a whole'. In reality and in the chapters in this article address competition across levels of analysis, and generally include interactions across at least two of these six layers. Figure 3.1 visualizes the layers, internally.

Figure 3.1 Four layers within the university: Who's competing?

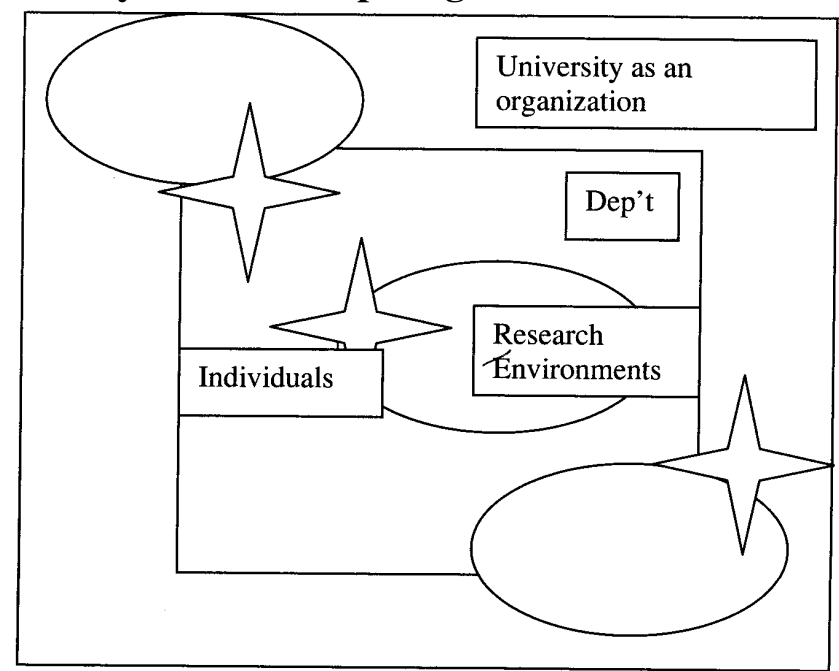

The first four layers represent ways of representing the inside of the university and HEIs. The last two layers are not included in Figure 3.1, but represent the broader external environment, which is affecting the four internal layers. 
1. Individuals

2. Research environments

\section{Departments}

4. University as an organization

5. National science and education system, including public policy

6. Global university sectoral innovation system

The first three layers relate to individuals, research environments and departments. Many years of research has demonstrated the importance of key individuals for science, and yet the research environment is also key, to enable collaboration and stimulate new endeavours. Departments refer to the organizational unit, which provides administrative support, organizes undergraduate education and usually retains many control functions. These three layers are crucial for understanding what goes on within universities and colleges, given the distributed nature of this type of knowledge work.

The fourth layer is the university as an organization. Here, one can analyze the university acting as a more or less coherent and cohesive organization, similar to how one discusses 'the firm' or 'the government agency'. Competition is affected by how the people leading the organization have defined some goals and direction, so that analysis may focus on the top offices (vicechancellor, rector, president) as well as on leadership roles such as faculties, deans, and committees. This layer is also affected by the organizational actions and outcomes at an aggregate level, such as recruitment policy, the total number of students educated, and whether more research is being published in top journals, within a time period.

The last two layers are the external ones of national science and education policy system and the global sectoral innovation system. These refer to the broader innovation systems, and as such, these are more the arenas within which specific universities and colleges can choose to compete. At the national context, one can analyze the 'university sector' as a population of actors or one can analyze national institutional variations, such as the existence of specialized 
research institutes in comparison to universities and the specific policies and institutions governing higher education. The global sectoral innovation system has been less studied than the other levels (except the sector for management education see e.g.Sahlin-Andersson \& Engwall 2002), but may be increasing in importance, due to internationalization, including the new global competitors and trends amongst students, researchers, and so forth.

We argue that university competition does take place at different layers, and for different 'customers' and stakeholders. Thus being clear about these layers is useful for designing future empirical work on how, why and whether universities are learning to compete. The most interesting ideas about strategy and competition likely centre around how several layers interact in specific processes.

\section{What are the service products for sale?}

At the most extreme, we could think of universities and colleges as a type of knowledge factory, delivering knowledge-intensive services. Even manufacturing companies making traditional industrial products have moved towards adding value through services, so this conceptualization is in line with much research on companies (Prencipe et al 2005). The question remains, what are universities and colleges 'selling'?

We put forth that universities and colleges are involved in three key areas of knowledgeintensive services are 'education', 'research' and 'societal interactions' especially commercialization.

Gallouj (2002) provides a review of literature about innovation in services, including the specificity of services as being consumed as they are produced, as involving some degree of customer participation; and as exhibiting extreme diversity. In a study of knowledge-intensive business services, Tether and Hipp (2002) review the literature to find the following specific characteristics of knowledge-intensive services: Close interaction between production and consumption; the intangible nature of service outputs; the key role of human resources in service provision; the critical role of organizational factors in firms' performance; and the weakness of intellectual property rights in services. 
This implies that the boundaries of the university will be rather 'fuzzy' when services involve consumption and production as well as that human resources and organizational factors will have large impacts on the successful delivery of these three knowledge-intensive services. Figure 3.2 shows that individuals and research groups are organized within departments at the university, in relation to the three knowledge intensive services on offer.

Figure 3.2 Knowledge-intensive service creating open boundaries in the university.

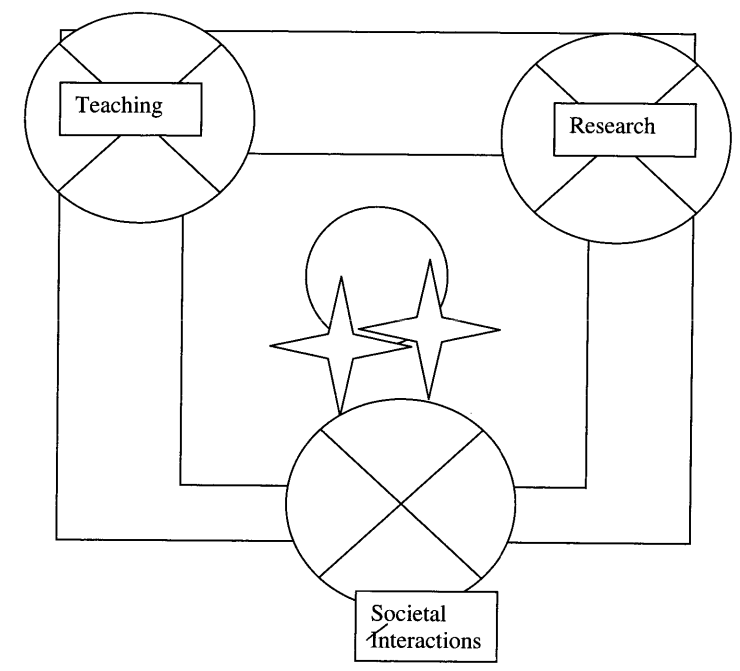

Much of the provision of the three knowledge-intensive services will directly involve those individuals, but also occur at the boundaries between the employees of the organization and other groups. To take an obvious example, students are an integral part of what makes a university, and often 'consume' their education on-site, and yet they are not employees. Figure 3.2 thus demonstrates how the delivery of the three types of knowledge-intensive services opens up the organization towards multiple stakeholders, while at the same time often requiring the involvement of multiple layers within the organization.

\section{Selection mechanisms and metrics ${ }^{\mathrm{vi}}$}

This section uses some of the previous concepts, in order to characterize how universities compete from the point of view of selection, that is how outside actors chose among existing or expected offers from different universities. So what is it that universities offer, if we go beyond the characteristics outlined above? From a more abstract perspective, universities are specialized organizations whose motivation for existence is the fact that knowledge is a scarce 
resource in society. Universities are a particular organizational form that is set up (almost) solely to alleviate the scarce knowledge problem in society. This is not a minor task as evidenced by the discussion of the 'knowledge society' where knowledge should be the most important asset for economic competitiveness, especially for firms and other organizations. This scarcity can occur in society, in two main ways, either as being poorly disseminated among actors or simply as genuine ignorance or lack of knowledge across the entire population. ${ }^{\text {vii }}$ The remedies for the problem of poorly disseminated knowledge as provided by the universities tend to come in the shape of education but also third mission activities while the problem of lack of knowledge tend to come in the form of university research.

We have outlined the three types of knowledge-intensive services that most universities offer individuals, firms or society, and the idea of scarcity helps us see why the university competes. Education is a knowledge-intensive service in the sense that universities provide students with new insights and skills by drawing upon the existing skills and competencies of its staff. Research is a knowledge-intensive service in the sense that the university is to discover, analyse, synthesize or test new knowledge and then disseminate its findings in society. It may do so by publication and teaching but also by setting up new companies those exploit the new knowledge, allowing society to purchase its findings. These are three ways in which the university as an organization provides its knowledge-based services. All three are knowledgebased services in the sense of being intangible offerings, often requiring a combination of producer and user interaction, as discussed in the previous section.

Universities can provide these knowledge-intensive services because someone is wiling to pay for (or purchase) them, through public or private funding. The nature of the scarcity depends on the constituency, that is for whom the organization exists (e.g. Morris 2005). For example, an undergraduate student is likely to be more interested in what and how a university teaches than its research or the university's commercial outreach or societal impact. At the same time, the interest of society and firms tend to be broader but also more indirect than the interests of individuals as they may be interested in the number and general quality of graduates rather than what these students know individually. Still, all constituents of universities have some interests in all types of university outputs, as they influence each other directly and indirectly. 
Nonetheless, this leaves us with the question of what the relation looks like between the services universities provide and the different wants and needs of its constituents - or 'customers'.

One broad answer can be found in the extensive bodies of literature that deals with how universities interact with its environment and on the overall role of science and of universities in society (ref Bush 1945, Nelson 1959, Arrow 1961, Etzkowitz 2003). Importantly, from a knowledge-based perspective, ample empirical analysis the unique contribution of basic science and how society benefit from scientific research and university activities. Thus, there is a long tradition of research has that have tried to specify the contributions of basic science and of universities per se to society (Mansfield 1991; Mansfield 1995;, Geuna and Nesta 2006; Salter and Martin 2001). These studies conclusively show that different types of public research as well as universities per se contribute to public and national objectives for society. While this literature generally focuses upon the contributions of research, it is sufficiently general to show a broader contextual understanding of what universities do for whom.

A literature review of the economic benefits of publicly funded research identifies seven channels for the economic benefits of publicly funded research (Salter and Martin 2001; Martin and Tang 2007). These are: 1) Increase in the stock of useful knowledge; 2) Supply of skilled graduates and researchers; 3) Creation of new scientific instrumentation and methodologies; 4) Development of networks and stimulation of social interaction; 5) Enhancement of problemsolving capacity; 6) Creation of new firms; and 7) Provision of social knowledge, such as policy-relevant knowledge.

Hence, in this section, we wish to link these seven mechanisms by which universities interact with society towards different types of 'customers', stakeholders or others whom are willing to pay and consume these intangible services. Table 4.1 therefore specifies the differing perspectives of three main groups of constituents - students, firms, and governments (or society). 
Table 4.1 University services and beneficiaries: benefit to different types of customers.

\begin{tabular}{|c|c|c|c|}
\hline $\begin{array}{l}\text { Type of } \\
\text { knowledge- } \\
\text { intensive service }\end{array}$ & Students & Firms & Goverment \\
\hline Education & $\begin{array}{l}\text { Training to create } \\
\text { skills and knowledge }\end{array}$ & $\begin{array}{l}\text { - Creation of } \\
\text { competent } \\
\text { employees } \\
\text { - Alleviation of } \\
\text { scarce human } \\
\text { capital }\end{array}$ & $\begin{array}{l}\text { - Allevation scarce } \\
\text { human capital } \\
\text { - Creation of } \\
\text { societal } \\
\text { capabilities }\end{array}$ \\
\hline Research & $\begin{array}{l}\text { Better 'proven' } \\
\text { knowledge }\end{array}$ & $\begin{array}{l}\text { - New or proven } \\
\text { knowledge } \\
\text { - Business } \\
\text { opportunities }\end{array}$ & $\begin{array}{l}\text { - Trained } \\
\text { professionals } \\
\text { - New Knowledge }\end{array}$ \\
\hline Third mission & $\begin{array}{l}\text { - Firms, business } \\
\text { and societal } \\
\text { connections } \\
\text { - Entrepreneurial } \\
\text { opportunities }\end{array}$ & $\begin{array}{l}\text { - Access to specific } \\
\text { problem-solving } \\
\text { skills } \\
\text { - Mentoring } \\
\text { - Diffusion of scarce } \\
\text { knowledge }\end{array}$ & $\begin{array}{l}\text { - New firms } \\
\text { - Diffusion of scarce } \\
\text { knowledge about } \\
\text { societal problems } \\
\text { - Identification, } \\
\text { analysis of the } \\
\text { nature of societal } \\
\text { problems }\end{array}$ \\
\hline
\end{tabular}

Let us then explain how Table 4.1 links the type of knowledge-intensive service, to the benefits expected from different types of customers in terms of these seven mechanisms.

Clearly, there are differences in that students are directly interested in the skills, knowledge and aptitudes they acquire while firms and government are more concerned with the general increase and dissemination of useful knowledge via supply of skilled graduates and researchers. The provision of the three knowledge-intensive services may be interlinked across customers and services. The interests of firms are more specific than governments, so that firms demand competent employees while governments are more concerned about creation of socially useful capabilities. Research as such is rarely directly useful to students but it can have many indirect effects, especially by making education more up-to-date. Firms can also find research to be relevant as it creates new problem-solving abilities or instruments may solve many of their business problems or provide them with new business opportunities. Finally, universities also 'sell' a whole range of third mission activities. While this is not the primary concern of 
students, they do tend to be interested in making connections with companies for future careers or starting up firms.

Table 4.1 above also has some distinct strategic and competitive implications for universities. A shift towards a new competitive regime where the selection of output determine which universities will become 'winners' and 'losers' could then be found in terms of various metrics that represent Table 4.1. Ways of quantifying the outputs of the universities and HEIs are 'metrics' such as number of publications and citations, and these can be seen as signals to potential consumers, whom compare different universities. When comparability across organizations becomes more important, then metrics in terms of outputs matter more. This is similar to the role of the price mechanism in more traditional market situations. The metrics used within a specific national context or region is clearly related to public policy decisions, such as whether to count publications, company start-ups or patents.

Note that the exact nature of the metrics does not need to be straightforward, or rather, they are often mitigated by other forces. In industry, firms do not just compete only by offering homogeneous products for a price but also in terms of other aspects like branding, reputation, and consumer loyalty. The same should hold true for universities.

Based on Table 4.1, a list of suggested metrics is shown in Table 4.2. ${ }^{\text {vii }}$ These should all reflect outputs of the interests of the different constituents along the three different university services. As student interests of education is in terms of its training, metrics corresponding to the output could be expected to be what type of courses they have had, whether they are likely to get a job and their (expected) future salary. An indirect output is also the prestige of their educational profile and their university as reflected by the perceived quality of other graduates. Firms are more likely to focus on the number of 'good enough' graduates that can be usefully employed, while the government should also be concerned with keeping unemployment figures down. ${ }^{\mathrm{ix}}$ 
Table 4.2 Example of metrics used by different customers in the university sector*: Metrics.

\begin{tabular}{|c|c|c|c|}
\hline $\begin{array}{l}\text { Type } \\
\text { offerings }\end{array}$ & Students & Firms & Government \\
\hline Education & $\begin{array}{l}\text { Types of courses; } \\
\text { employability; } \\
\text { expected employment } \\
\text { and salary; } \\
\text { reputation, prestige } \\
\text { and } \\
\text { university/educational } \\
\text { ranking }\end{array}$ & $\begin{array}{l}\text { Number of } \\
\text { graduated with } \\
\text { relevant profiles }\end{array}$ & $\begin{array}{l}\text { Number and type } \\
\text { students and graduates, } \\
\text { deflation } \\
\text { unemployment } \\
\text { numbers }\end{array}$ \\
\hline Research & $\begin{array}{l}\text { Prestige and } \\
\text { university ranking }\end{array}$ & $\begin{array}{lr}\begin{array}{l}\text { New } \\
\text { exploitable }\end{array} & \text { proven } \\
\text { knowledge } \\
\text { (patents), }\end{array}$ & $\begin{array}{l}\text { - New proven } \\
\text { knowledge } \\
\text { - Prestige research } \\
\text { (mass media coverage, } \\
\text { university rankings) }\end{array}$ \\
\hline Third mission & $\begin{array}{l}\text { Employability } \\
\text { - Prestige }\end{array}$ & $\begin{array}{l}\text { - } \quad \text { Employability } \\
\text { - } \quad \text { Problem-solving } \\
\text { skills and advice } \\
\text { - } \quad \text { Spin-offs } \\
\text { - } \quad \text { Meeting places }\end{array}$ & $\begin{array}{l}\text { - Employability } \\
\text { - National and regional } \\
\text { prestige and } \\
\text { development. } \\
\text { - Guidance of societal } \\
\text { concerns and debates } \\
\text { - Spin-offs } \\
\text { - Meeting places }\end{array}$ \\
\hline
\end{tabular}

*Note: many of the listed metrics are already in use. For example "New proven knowledge" can be assessed in the number of publication, paper citation and the number of patent. There are many examples of "university/educational ranking" such as the Financial Times list of rankings of MBA (master of Business Administration) programmes around the world

In terms of research, students should be concerned with the prestige they can draw as reflected in research announcements, while firms would both be concerned with the creation of potential highly skilled employees (PhDs) and access to exploitable knowledge. In addition, governments would find demonstrated knowledge relevant but also more prestige related issues such as the number of leading universities or research groups as compared to other nations.

Finally, students are likely to look for employability and prestige as a reflection of the outcome of Third Mission activities. Firms would view Third Mission activities to increase the likelihood of employability of students, but would also be interested in the existence and size of meeting places or the number of spin-offs in a region from a university. In addition, 
governments would likely care about national or regional prestige stemming from Third Mission activities as well as being able to identify perceived experts that can be enrolled whenever some nationally strategic question arises.

In conclusion, there are strategic implications for how universities will act based on the metrics based selection logic outlined above. Metrics form a type of selection mechanism, where there are feedback loops so that strong performers on one or several important metrics are rewarded for what they have accomplished, while poorly performing universities are punished.

Clearly, this means that universities will try to act strategically to improve their standing on important metrics - or else try to change the metrics by which they are judged. To begin with, European universities are already working to improve their standing on important metrics, and to do so, they are using internal and external review panels, based upon specific criteria and lists of acceptable journals.

However, there are different constituents, and some but not all metrics may be difficult to combine in the same organization. Consequently some universities will focus only upon a few, where they seem to be more likely to be successful. This means that different universities will attempt and learn to specialize to score high on very specific metrics. Thus, positive and/or negative feedback based on relative performance on metrics will reinforce specialization. Moreover, some universities will still perform poorly on existing metrics, regardless of the constituency. Or, they may wish to retain their reputation, by being involved in all three types of knowledge-intensive services. These considerations matter greatly in a world characterised by scarce resources and where the relative performance in terms of outputs is correlated to the amount of resources the universities can get hold of. Consequently, poorly performing universities need to do something to stay in the game, and not only competing for market shares (e.g. expansion of students). These universities can do so by trying to change the rules of the competitive game, in order to improve their standing. One way is to create additional and new metrics, that can be thought of as tailor made metrics that should fit their particular profile. Another alternative is to point out those existing measurements and indicators are inherently limited (or even downright erroneous). ${ }^{\mathrm{x}}$ 
This idea about metrics and feedback mechanisms can be used to assess the relative degree of how far countries have advanced along shifting their university sector more towards the new competitive regime. The reason is straightforward. The more a nation has shifted towards the new competitive regime, the greater explanatory power that we can find in the universities 'market share' in terms of research funding, amount of high paying or highly talented students, the amount of spinoffs etc. This can provide one way to scrutinize the relative amount of 'university competition' rhetorics compared to whether the actual performance really results in e.g. larger market share of research funding for good performers. It can also provide insight into how specific organizations - or the national context - provide ways 'around' the new competitive regime, allowing for business as usual for the universities. 


\section{Discussion}

This article has addressed what competition may mean for the universities. While we recognize the validity of many arguments about the specific nature and context of universities, colleges and HEIs, one of the points of this chapter is to see how far that we can push the argument that universities do compete, and that the way they compete are changing. We have done this to explore where and how universities can be analyzed using tools traditionally reserved for industries and firms.

We find them sufficiently similar to firms and competition to push the argument further. From the above discussion, we propose that:

5. Individual universities can decide to try to strategically assess their competencies and capabilities, in order to position themselves to compete in the future. They do so in relation to three knowledge-intensive services and their relative importance is determined by different constituencies (market segments).

6. Universities have to develop knowledge assets, which may be developed internally or which may be sourced externally through mechanisms such as collaboration. These are keys to providing the goods and services demanded within the higher education sector.

7. Selection mechanisms based on metrics (indicators) are usually related to different customers, and a specific university will have difficulties in maximizing all of the metrics (the term de-harvardization was coined to describe that even Harvard is unable to supply all subjects).

8. The correlation and causation between how universities perform on different metrics and various forms of market shares can be analysed to capture how far nations have gone towards a new competitive regime as compared to the regimes of social institutions, financed by public monies to produce public goods. 
From a university perspective, these knowledge-intensive services are all activities in which individuals, groups, departments, and the organization as a whole participate and shape. Clearly, as this process proceeds, conflicts do arise between activities and between different parts of the university. Trying to deliver upon these different domains of activities usually involves difficult choices, involving trade-offs between different sets of metrics, priorities and desired effects. Moreover, providing knowledge-intensive services can be carried out by separate parts of the organization, or else the same people can be involved within all types of activities. This implies that rather than treating the university as one entity, future research needs to further define and refine how, why, and what levels these changes are occurring - as well as identifying what is being lost in the new competitive regimes. This article has suggested some ways in which the individual organizations and the sector can be analyzed, understood, and managed as providing knowledge-intensive services to different customers, and under different forms of selection mechanisms.

European academics do seem to be entering a transition, because they are facing new internal and external pressures to change and conform to a competitive regime, within the university sector. They face deregulation at national level of education and less direct funding. Many governments want teaching factories, rather than elitist organizations - although quality research also has high prestige. Goals are often conflicting, between different knowledge based services. In some national institutional settings, research is still clearly financed by the state and in other national settings; researchers must find external funding, sometimes accompanied by an assumption that external monies certify high quality of research. This implies that the conceptualization of what a university is, how it works, and what benefits it provides to society are changing, but may also be quite different in various European countries. Despite that diversity, all the European universities seem to be struggling with renewal of education and research, with maintaining traditions as well as incorporating new tasks. Given our broader view of competition as a dynamic process, requiring innovation and specialization, we could predict and identify attempts by HEIs to consolidate position and to compete through knowledge based services. The question of strategy and how to compete then arises, as do their attempts to change the national institutional setting and selection environment, to fit their own profile and goals. 


\section{References}

Aghion, P., P. Fally and S. Scarpetta (2007) 'Credit constraints as a barrier to the entry and post-entry growth of firms', Economic Policy, 22 (52), 731-779

Amit, R. and C, Zott (2001), 'Value Creation in E-Business', Strategic Management Journal, 22, 493-520

Asheim, B., P. Benneworth, L. Coenen, and J. Moodysson (2006), 'Co-evolution in Constructing Regional Advantage: Multiple Roles of Lund University in Strengthening the Scania Regional Innovation System', LIEE / NTUA, Athens, December 20006. http://dimeliee.ntua.gr.

Bauer, M., B. Askling, S.G. Marton and F. Marton (1999), Transforming Universities.

Changing Patterns of Governance, Structure and Learning in Swedish Higher Education, London: Jessica Kingsley.

Birnbaum, Robert (1990), How Colleges Work. The Cybernetics of Academic, Organization and Leadership. San Francisco and Oxford: Jossey-Bass Publishers.

Bonnacorsi, A., Daraio, C., (eds) (2007), Universities and Strategic Knowledge CreationSpecialization and Performance in Europe, Edward Elgar Publishing.

Braunerhjelm, Pontus and Maryann P. Feldman (2006), Cluster Genesis: Technology-based Industrial Development, Oxford: Oxford University Press.

Bush, V.annevar(1945), Science and the Endless Frontier, Washington D.C.: National Science Foundation.

Butler, L. (2003), 'Explaining Australia's Increased Share of ISI Publications - The Effects of Funding Formula Based on Publication Counts', Research Policy, 32 (1), 143-155.

CAE (2007), Contributions to Colleges and Universities, Council for Aid to Education, www.cae.org

Chesbrough, H. and R. Rosenbloom (2002), 'The Role of the Business Model in Capturing Value from Innovation: Evidence from Xerox Corporation's Technology Spin-off Companies', Industrial and Corporate Change, 11(3), 529-555. 
Cooke, Philip and Andrea Piccaluga (eds) (2004), Regional Economies as Knowledge Laboratories, Cheltenham, UK and Northampton, MA, US: Edward Elgar.

Dasgupta, P. and P.A. David (1994), 'Toward a New Economics of Science', Research Policy, 23 (5), 487-521.

David, P.A. (1994), 'Positive Feedbacks and Research Productivity in Science: Reopening Another Black Box', in Ove Granstrand (ed.), Economics of Technology, Amsterdam, North Holland, and London: Elsevier.

Dahmén, E. (1950), ‘Svensk industriell företagarverksamhet: kausalanalys av den industriella utvecklingen 1919-1939', Stockholm, Industrins utredningsinstitut.

Eliasson, G., (1990), 'The Firm as a Competent Team', Journal of Economic Behaviour and Organization, 13, 275-298.

Engwall, L. (2007), 'The University: A Multinational Corporation?', Paper for the Academia Europea and Wennergren Foundations Conference "The University in the Market Place", Stockholm, November 1-3 2007.

Etzkowitz, Henry and Loet Leydesdorff (1997), Universities and the Global Knowledge Economy: A Triple Helix of University-Industry-Government Relations, London, Cassel.

Etzkowitz, H (2003). 'Research groups as 'quasi-firm': the invention of the entrepreneurial university', Research Policy, 32, 109-121.

Fuller, Steve (2000), The Governance of Science, Open University Press.

Frølich, N, 2008, 'The politics of steering by numbers - Debating performance-based funding in Europe' NIFU STEP Rapport 3/2008.

Geuna, A. and L.J.J. Nesta (2006), 'University Patenting and Its Effects on Academic Research: The Emerging European Evidence', Research Policy, 35 (6), 790-807.

Hanusch, Horst and Andreas Pyka (eds) (2007). Elgar Companion to Neo-Schumpeterian Economics. Cheltenham, UK and Northampton, MA, US: Edward Elgar.

Hayek, F. A. (1937), 'Economics and Knowledge', Economica, 4 (13), 33-54.

Hicks, D. (2007), 'University System Research Evaluation in Australia, the UK and US', Georgia Tech Working Paper Series, No. 27.

Holmén, M., M. Magnusson and M. McKelvey (2007), 'What are Innovative Opportunities?', Industry and Innovation, 14 (1), 27-45. 
Gallouj, Faïz (2002), Innovation in the Service Economy: The New Wealth of Nations, Cheltenham, UK and Northampton, MA, US: Edward Elgar.

Klevorick, A.K., R.C. Levin, R.R. Nelson and S.G. Winter (1995), 'On the Sources and Significance of Inter-industry Differences in Technological Opportunities', Research Policy, 24, 185-205.

Knight, Frank H. (1921), Risk, Uncertainty and Profit, New York: Harper.

Lane, D. A. and R. R. Maxfield (2005), 'Ontological Uncertainty and Innovation', Journal of Evolutionary Economics, 15, 3-50.

Lepak, D.P., K.G. Smith and M.S. Taylor (2007), 'Value Creation and Value Capture: A Multilevel Perspective', Academy of Management Review, 32 (1), 180-94.

Magretta, J. (2002), 'Why Business Models Matter', Harvard Business Review, May, 3-8.

Markides, C. and C. Charitou (2004), 'Competing with dual business models: A contingency approach', Academy of Management Executive, 18 (3), 22-36.

McKelvey, Maureen (1996), Evolutionary Innovations: The Business of Biotechnology, Oxford, Oxford University Press.

McKelvey, Maureen and Magnus Holmén (eds) (2006), Flexibility and Stability in the Innovating Economy, Oxford: Oxford University Press.

Malerba, Franco (2006), Sectoral Systems of Innovation, Cambridge: Cambridge University Press.

Mansfield, E. and J.Y. Lee (1996), 'The Modern University: Contributor to Industrial Innovation and Recipient of Industrial R\&D Support', Research Policy. 25, 1047-1058.

March, J.G. (1996), 'Continuity and Change in Theories of Organizational Action', Administrative Science Quarterly, 41 (2), 278-287.

Martin, B.R. and P. Tang, 'The Benefits from Publicly Funded Research', SPRU Electronic Working Paper Series, No. 161.

Menger, Carl, (1871), Grundsätze der Volkswirtschaftslehre. Translated 1981, Principles of Economics, New York, New York University Press.

Merton, Robert K. (1973), The Sociology of Science: Theoretical and Empirical Investigations, Chicago: Chicago University Press. 
Metcalfe, J. S. (1998), Evolutionary Economics and Creative Destruction, London, Routledge. Morris, M., M. Schindehutte and J. Allen (2005), 'The Entrepreneur's Business Model: Towards a Unified Perspective', Journal of Business Research, 58, 726-735.

Mowery, D., R. R. Nelson, S. Sampat and A. Ziedonis (2001). 'The Growth of Patenting and Licensing by U.S. Universities: An Assessment of the Effects of the Bayh-Dole Act of 1980'. Research Policy, 30, 99-119.

Musgrave (1987), Public finance in a democratic society: collected papers of Richard A. Musgrave. Vol. 1, Social goods, taxation and fiscal policy, New York, New York University Press.

Nelson, R.R. (1959), 'The Simple economics of Basic Scientific Research', The Journal of Political Economy, 67 (3), 297-306.

Nelson, Richard R. and Sidney Winter (1982), An Evolutionary Theory of Economic Change, Cambridge, MA, US: Harvard University Press.

Nelson, Richard R. (1996), The Sources of Economic Growth, Cambridge, MA, US: Harvard University Press.

Nowotny, H, Scott, P \& Gibbons, M (2001). Re-Thinking Science: Knowledge and the Public in an Age of Uncertainty, Cambridge, Polity Press.

Park, D (1998), 'The Meaning of Competition: A Graphical Exposition', Journal of Economic Education, 29 (4), 347-357.

Penrose, Edith. T. (1959), The Theory of the Growth of the Firm, Oxford: Blackwell.

Foster, John and Jason Potts (2006), 'Complexity, Evolution, and the Structure of Demand'. In M. McKelvey and M. Holmén (eds), Flexibility and Stability in the Innovating Economy, Oxford: Oxford University Press.

Prencipe, A., Davies, A. And Hobday, M. (2005), The Bussines of Systems Integration, Oxford, Oxford University Press

Romer, P. (1986), 'Increasing Returns and Long-Run Growth', The Journal of Political Economy, 94 (5), 1002-1037

Salter, A.J. and B.R. Martin (2001), 'The Economic Benefits of Publicly Funded Basic Research: A Critical Review', Research Policy, 30, 509-532. 
Saviotti, P. and J. Krafft (2004), 'Industrial Dynamics, Innovation and Development', Paper presented at DRUID summer conference 2004, Denmark.

Sahlin-Andersson, K., Engwall, L., (eds) (2002), The Expansion of Management Knowledge: Carriers, Flows and Sources, Stanford, CA: Stanford Business Books

Schumpeter, Joseph A. (1942), Capitalism, Socialism, and Democracy, New York and London: Harper \& brothers.

Shils, Edward A. (1997), The Calling of Education: "The Academic Ethic" and Other Essays on Higher Education. Chicago: University of Chicago Press.

Shane, Scott (2004), Academic Entrepreneurship: University Spinoffs and Wealth Creation, Cheltenham, UK and Northampton, MA, US: Edward Elgar.

Shattock, Michael (2003), Managing Successful Universities, Buckingham: Open University Press.

Slaughter, Sheila and Larry L. Leslie (1997), Academic Capitalism: Politics, Policies, and the Entrepreneurial University, Baltimore, US and London, UK: The Johns Hopkins University Press.

Slaughter, Sheila and Gary Rhoades (2004), Academic Capitalism and the New Economy, Baltimore, US and London, UK: The Johns Hopkins University Press

Slywotsky, Adrian J. (1996), Value Migration. How to Think Several Moves ahead of the Competition, Boston, MA, US: Harvard Business School Press.

Stephan, P., (1996), 'The Economics of Science', Journal of Economic Literature, 34 (3), 1199-1235.

Stiglitz, J E, (1993), 'Welfare Economics with Imperfect and Asymmetric Information', Lindahl Lectures presented at Uppsala. Oxford University Press, Oxford.

Tether, B.S. and C. Hipp (2002), 'Knowledge Intensive, Technical and Other Services: Patterns of Competitiveness and Innovation Compared', Technology Analysis and Strategic Management, 14 (2), 163-182.

Vincent-Lancrin, S. (2006), 'What is Changing in Academic Research? Trends and Future Scenarios'. European Journal of Education, 41 (2),169-202. 
Ziman, John M. (2000), Real Science: What it is, and what it means, Cambridge: Cambridge University Press. 


\section{Footnotes}

\footnotetext{
${ }^{\mathrm{i}}$ Universalism means that the personal and social attributes of the researcher should not affect the perceived validity of the conclusions. Disinterestedness means that the beliefs should not be biased by authority, and communism refers to open communication and common ownership of knowledge.

ii The present authors found this debate to be extremely interesting, and it stimulated the book project.

iii The output of HEIs has traditionally been handled as a merit good that is a commodity that should be distributed to an individual or society by other means than consumer preferences (Musgrave 1987). And it is assumed that merit good are under consumed or under produced because they create positive externalities which arises form the consumption or production of the good or services. Further since individuals are myopic they might not take into account the long-term benefits of consuming a merit good and education has often been taken as an example of this. Clearly, merit good does not have to be provided by government as is shown by recent development in primary education and management education. For instance, US experience with charter schools have shown how dynamic competitive elements can be introduced in the provision of education.

${ }^{\text {iv }}$ Based upon previous work found we have decided to differentiate whether the definitions are primarily static or dynamic; whether they are primarily concerned with the overall system or focus upon actors; and whether the focus is upon exchange of resources within the market system or upon the accumulation of resources within the
} organization (McKelvey and Holmén 2006, Holmén et al 2007).

${ }^{v}$ Competition is often indirect as modern economies are characterized by a high division of labor (e.g. Knight 1921). This means that an actor competes over resources in one area to improve its standing in another. Often the rewards are financial but other means for satisfying wants and needs are also important.

${ }^{\text {vi }}$ One way actors compete is how they construct their business model. The business model is can be viewed as the 'script' or 'logic' by which economic value is extracted from resources in association with one or several business opportunities. Central to the business model is how value is created for the customer and how the innovating firm appropriate economic value. From a dynamic and forward looking aspect the firms attempts to create value and appropriate returns from its investments. Value is a subjective notion that relates to the perceived wants or needs of a user and is thus here defined from the user(s) perspective (Menger 1871, Lepak et al 2007). A business model includes the activities from making something to reaching customers, distributing the products, designing the revenue model and so on (Amit and Zott, 2001; Chesbrough and Rosenbloom, 2002; Magretta, 2002; Markides and Charitou, 2004; Morris et al., 2005). Therefore, the business model refers to the customer segments that are being defined and served and the customer offering, which activities should be and is performed in-house and which should be outsourced, how the firm configures its resources, what the position is/should be in the value network, how the firm sells and distributes its offering and what value is created for the customer and by what means a profitable and sustainable part of that value is appropriated through its revenue model. The activities of the firm is thus to participate in forward looking value creation activities under uncertainty, and to appropriate and capture a part of the forthcoming value.

vii There is also a third aspect, retention or remembrance in the sense that universities can be thought of as consisting as a specialized collective memory.

viii Of course, these metrics can be converted to quantitative measures and/or be assessed by indicators.

${ }^{\text {ix }}$ As the goals of having a low unemployment but also a high quality in an education may be incommensurable, this is an example that different metrics may be contradictory.

${ }^{\mathrm{x}}$ The universities that are likely to be winners are the ones that can align their knowledge base with their services while reaping increasing returns. With this combination in place, they will receive positive feedback compared to other universities allowing them to use their advantage to invest in new knowledge assets. The winners here are the ones that do more by knowing less. That means to specialize so as to reuse knowledge in some domain(s) time and time again in order to improve their scoring on the particular metrics that matter. When the selection mechanism in terms of comparability becomes more important, the metrics in terms of outputs matter more. This argument is closely connected with the above point as 'losers' in one metric over time may need to shift their emphasis to other domains. 
